\title{
ECONOMIC PATRIOTISM AFTER THE CRISIS: EXPLAINING CONTINUITY AND CHANGE IN EUROPEAN SECURITIES ENFORCEMENT
}

\author{
Chase Foster \\ Harvard University
}

\begin{abstract}
Since the global financial crisis, European governments have sought to intensify the supervision of financial markets. Yet, few studies have empirically examined whether regulatory approaches have systematically shifted in the aftermath of the crisis, and how these reforms have been mediated by longstanding national strategies to promote domestic financial interests in the European single market. Examining hundreds of enforcement actions in three key European jurisdictions, I find a mixed pattern of continuity and change in the aftermath of the crisis. In the UK, aggregate monetary penalties and criminal sanctions have skyrocketed since 2009, while in France and Germany, the enforcement pattern suggests continuity, with both countries assessing penalties and prosecuting insider trading at similar rates before and after the crisis. I conclude that financial regulation is still structured by longstanding industrial strategies (Story and Walter, 1997), but where pre-existing regulatory approaches were seen as contributing to the crisis, a broader regulatory overhaul has been pursued. Thus, in the UK, where the financial crisis served as a direct rebuke to the country's "light touch" regulation, financial supervision was overhauled, and monetary sanctions dramatically increased, to preserve London's status as an international financial centre. By contrast, in France and Germany, where domestic regulatory systems were implicated by the financial crisis, domestic securities supervision and enforcement was less dramatically altered. While the crisis has led to the further institutionalization of European-level supervisory institutions, these changes have not yet led to convergence in national regulatory approaches.
\end{abstract}




\section{Introduction}

Since 2008, European financial market regulation has been transformed. Several dozen new directives and regulations have been enacted at the European level that intensify the detail and reduce the flexibility of existing rules while broadening the scope of European regulation to new areas, such as credit rating agencies, hedge funds, and banker bonuses (Lannoo 2013; Moloney 2016; Goldstein and Véron 2011). A new Paris-based European Securities and Markets Association (ESMA) has been established to harmonize supervisory and enforcement approaches across jurisdictions, while national market conduct regulators have been provided broader surveillance and enforcement powers. Across nearly all European jurisdictions, the number of staff dedicated to supervision and enforcement has increased since 2008.

Many of the new initiatives and regulatory approaches are qualitatively different from past regulatory efforts. While before the crisis, the focus of regulation was largely on "market making"-removing barriers to entry and enforcing competition rules seen as enhancing market efficiency, while generally trusting the 'free market' to ensure financial stability and investor protection - the post-crisis European regulatory landscape is largely oriented toward "market shaping": initiatives such as consumer protection and financial stability that do not take for granted market rationality (Quaglia 2012). Additionally, the approach to European financial services integration has shifted from systems of "mutual recognition," minimal standard setting, and loose coordination through regulatory networks that predominated before the crisis (Mügge 2011; Coen and Thatcher 2008), to more intensive harmonization efforts designed to standardize supervisory questions to the maximum extent possible (Moloney 2011). Even in the United Kingdom (UK), which houses Europe's largest capital markets and was previously the chief advocate of the market-making approach, regulators have shifted from a "principles-based" approach to supervision and "light-touch" application of enforcement, which predominated before the crisis, to a "rules-based" supervisory system that is more interventionist and deterrence-oriented in enforcement (Mügge 2013a; Tomasic 2010).

Yet, despite the "epochal" nature of the transformation in regulatory governance (Moloney 2011, 43 ), it remains unclear to what extent patterns of national regulatory enforcement have actually changed in the aftermath of the crisis, and how ongoing reforms have been influenced by national industrial strategies. Only a handful of political economy studies have examined post-crisis reform strategies, and few of these closely examine enforcement practices. Moreover, many of the extant enforcement studies either focus on single countries or analyze pre-crisis trends. To what extent has the post-crisis promise to intensify supervision and establish more stringent systems of enforcement led to changes in practice? How have these changes varied across jurisdictions? And in what ways have national financial interests continued to limit and shape securities enforcement in practice?

Drawing from close empirical analysis of enforcement statistics and reports, as well as interviews with regulators, this article undertakes a close examination of the enforcement patterns in financial regulation before and after the crisis in the UK, France, and Germany, the largest European member states and home to Europe's most important financial markets. I find wide variation in the extent to which regulatory practices have changed since the crisis. In the UK, aggregate penalties have gone up forty-fold, and criminal prosecutions for insider dealing increased from zero before the crisis to dozens since 2009. By contrast, in France, the regulatory approach in the securities 
field has been marked more by continuity, and in Germany, the shift toward a more coercive and adversarial regulatory approach is being implemented only gradually.

Building on Story and Walter's (1997) account, and Woll and Clift's (2013) work on "economic patriotism" in open markets, I argue that important continuities can be observed in each country's financial policy goals before and after the crisis, including the UK's commitment to full liberalization with minimal European rule making, the French focus on building more centralized European supervisory structures, and Germany's approach of incremental liberalization and reregulation combined with continued protections for its cooperative and public savings banks.

The differing patterns of regulatory change since 2009 can be explained by different experiences of the crisis. Where a country's pre-crisis regulatory approach was seen by policymakers as contributing to the financial meltdown, supervisory practices have been substantially altered.

In the UK, where the financial crisis was a direct rebuke to the UK's light-touch regulatory approach, and where finance is both highly internationalized and marketized, the political class overhauled financial supervision and instituted more adversarial strategies of enforcement in order to preserve London's status as an international financial centre. By contrast, in France and Germany, where domestic regulatory systems were not as implicated by the financial crisis, enforcement approaches changed less dramatically. Both countries instead sought to re-regulate on the international and European levels to address not only the problems of 'regulatory arbitrage' that had contributed to the crisis, but also to ensure that the post-crisis regulatory architecture protected domestic interests.

In sum, countries continue to promote national financial interests within the Single European Market, but because the crisis had different implications for domestic regulatory arrangements, we observe different patterns of change. Where domestic regulatory systems were delegitimized by the crisis, as in the UK, practices were overhauled as regulators identified failures in past practices and developed new supervisory strategies. But where pre-crisis regulatory practices were generally seen as effective, as in France and Germany, supervisory approaches have stayed more or less the same.

\section{Theoretical Perspectives}

In their classic account of the political economy of European financial integration, Story and Walter (1997) characterize the development of a single European financial market as a "battle of the systems" between the dominant economies of the UK, France, and Germany, with each country vying for regulatory rules and enforcement systems that would best position domestic financial centres and firms to benefit from market integration. In the UK, where capital markets were welldeveloped, financial liberalization and internationalization was an opportunity to further extend its international dominance: policymakers correctly believed that London would attract much of the financial market activity of a newly consolidated European market. In France, where state-owned financial institutions had predominated for much of the postwar period, but where a concerted effort at privatization was ongoing, the new European Single Market was an opportunity to modernize and expand French finance through a partially protected European financial market. In Germany, where an entrenched three-pillar banking system and coordinated model of capitalism was threatened by 'cosmopolitan' finance, the posture was more defensive, with governments 
seeking to protect German cooperative banks and locally-oriented Sparkassen within the newly liberalized environment, while simultaneously supporting extensions of European regulatory control over London, promoting Frankfurt as a financial centre, and advancing the interests of a small number of large, private banks in foreign markets (Story and Walter 1997, 275-306; Deeg 1999). Thus, in negotiations over the rules of the single market, the UK sought full liberalization with minimum re-regulation, France gradual liberalization with strong re-regulation on the European level, and Germany partial liberalization and home-control over supervision.

Since Story and Walter's (1997) account twenty years ago, several interrelated developments have challenged these earlier strategies. First, the broad processes of globalization and liberalization have led to the growth of capital markets in bank-dominated countries, rendering national financial systems more difficult to distinguish (Hardie et al. 2011; Hardie and Howarth 2009). Liberalization has also loosened state ties with major industries and financial institutions, making the industrial policies of the past more difficult to achieve in practice. For instance, the system of crossshareholding that allowed for public steering has disappeared as the French economy has liberalized (Morin 2000), and there is evidence that the much-vaunted German universal bank model has been undermined by EU state aid rules (Grossman 2006) and the decline of coordination between German companies and financial institutions (Höpner and Krempel 2004).

Second, ongoing Europeanization of financial services rules has gradually reduced state control over certain areas of regulatory policy. Most consequential has been the adoption of the euro by all of the major European countries except for the UK. This has led not only to a greater level of de facto financial market integration across countries, but also to larger and more powerful financial actors calling for further capital market integration and European re-regulation (Mügge 2011). Since European-level initiatives generally do not reflect the approach of any national system-promoting instead an external "international" approach to regulation-Europeanization may have further undermined possibilities for varieties of capitalism (Posner and Véron 2012).

Finally, the financial crisis, by spurring domestic financial reforms in a more punitive direction, and by moving key enforcement questions from national capitals to Brussels and Paris, may have fundamentally delimited national industrial strategies (Moloney 2011). The new centralization of supervisory and enforcement questions has only intensified the scope and reach of European rules. Many of these new rules are implemented as regulations, which, unlike directives, cannot be altered by member states, while the delegation of significant rulemaking authority to the European Securities and Markets Association adds to the pressure for more intensive enforcement.

Yet, while these developments have complicated the traditional strategies of industrial policy, they have not rendered them impossible. Undoubtedly, the neat distinctions once made between national financial systems are no longer possible in a financially globalized world, while the steady drumbeat of Europeanization has made national regulatory systems more interdependent and superficially similar. But while national financial systems have become more intertwined and financial structures more similar, the level of concentration in national banking systems, the degree of intermediation with industry, the size and breadth of capital markets, and the relative strength of national banks within the European market all remain different across countries in some important ways. The capital markets in the UK are, as a percentage of GDP, roughly three times larger than in Germany and around twice as large as in France, while bank credit composes a much larger share of corporate financing in Germany than in France or the UK (Howarth and Quaglia 
2013). And while the EU's Financial Services Action Plan did succeed in harmonizing the content of securities regulation (Mügge 2011), the Lamfalussy process, which aimed to standardize enforcement, largely proved incapable of promoting wholesale changes on the national level (Moloney 2011, 18), allowing states significant space to adapt the implementation of European securities rules to their national financial systems (Grossman and Leblond 2011). Finally, while open markets and competition rules have made it more difficult to promote 'national champions' (Shonfield 1965) or direct capital toward favored projects (Zysman 1983), states have still been able to pursue what Clift and Woll (2013) term "economic patriotism," defined as "the defense of local prerogatives in integrated markets" (308). Over the past few decades, European states have selectively pursued liberalization, showed regulatory forbearance for favored industries, and enacted stringent regulatory rules in sectors where domestic industries were less competitive visà-vis foreign firms, all to promote or protect certain industries. In the aftermath of the crisis, then, we might expect to observe similar instances of economic patriotism under the cover of liberalization or re-regulation.

\section{Financial Enforcement Before and After the Crisis}

\section{United Kingdom}

In the UK, financial regulation has been governed historically by a mostly informal, cooperative system of state regulation that provided self-regulatory organizations staffed by industry representatives with ample discretion to apply the law in loose coordination with the Bank of England (Johal et al., 2012; Moran 1986). Margaret Thatcher's "Big Bang" and the establishment of the Financial Services Authority (FSA) in the 1990s was thought to portend a more adversarial and legalistic regulatory process (Vogel 1996; Kelemen 2006), but in practice, the regulator maintained a comparatively cooperative approach to enforcement as a way to foster the City of London's attractiveness as a financial centre, seeking to avoid direct intervention into the affairs of financial actors, rarely assessing monetary penalties, and finding alternatives to punitive actions whenever possible (Tomasic 2010; Ferran 2006; Goodhart 2001). Conservative and Labour governments alike actively promoted the City's interests, often hailing their light-touch system as a friendlier alternative to the adversarial and legalistic American regulatory state (Morgan 2012; Kagan 2003), and seeking strong liberalization rules in Brussels that removed barriers to financial flows, but largely left re-regulatory questions to domestic authorities (Quaglia 2011; Mügge 2011). In the short term, willful regulatory forbearance proved to be a successful economic development strategy: on the eve of the crisis, London hosted twice the number of foreign banks as in the US, was the site of $63 \%$ of European IPOs (International Public Offerings) in terms of value, and boasted the world's largest share of international bank lending (Talani 2011, 22). Meanwhile, the share of domestic GDP stemming from financial services and related accounting, law, and management consultancy industries had risen from 8\% in 1997 to 15\% in 2007 (Morgan 2012, 379).

That the UK had a comparatively light-touch regulatory approach is borne out in the regulatory enforcement data. Aggregate penalties imposed by UK regulators in the early 2000s were just $1 / 30$ th the size of the securities penalties assessed in the US, even after controlling for differences in market size (Jackson 2007). While the Securities and Exchange Commission (SEC) devoted 40\%

of its budget to enforcement, the FSA spent just 12\%, and whereas American authorities criminally 
prosecuted scores of securities offenses each year, the UK almost never recommended criminal prosecutions for market abuse, despite internal reports at the FSA finding trading on insider information to be a common practice (Coffee 2007, 265-266). Throughout the 2000s, even as supervisory problems were revealed, instances of insider trading were made known, and financial institutions collapsed, UK regulators continued to defend light-touch as necessary to preserve London's status as the world's leading financial centre (Tomasic 2010, 19-20; Mügge 2013a).

That is, until the financial crisis hit. If the global financial meltdown that reached its climax in October 2008 with the collapse of Lehman Brothers was difficult for political and economic elites around the world, it was wholly traumatic in the UK, where three of four of the country's largest banks had to be nationalized, and more than $£ 1.1$ trillion spent in bank capital injection and guarantees to shore up its financial system (Woll 2014). Almost immediately, longstanding scripts about the benefits of light-touch regulation were torn up and, as the extent of the regulatory failure was made increasingly clear by parliamentary inquiries such as the Turner Report, the FSA engaged in an extensive re-writing of its rulebook (Froud et al. 2010). Although few questioned whether financial services would remain at the centre of the British economy, a new consensus among politicians, opinion leaders, regulators, and even bankers eventually emerged that, to maintain London's dominance in global markets, a new regulatory approach was needed (ibid.). As stated in Lord Turner's 2009 report, the Authority's approach would now be "underpinned by a different philosophy of regulation" that is both "more intrusive and more systemic" (Financial Services Authority 2009, 88). This new philosophy would do little to undermine the hegemony of finance, but it would entail a significant overhaul of financial supervision and enforcement, including the establishment of a new Financial Conduct Authority (FCA) to replace the malesteemed FSA, and an intensification of regulatory sanctions and prosecutions.

Table 1 reports the FSA and FCA's administrative penalties from 2004-2014. The clear increase in the frequency and size of penalties during the post-crisis period shows that the new philosophy did translate into changes in practice. Before Lehman Brothers collapsed in September 2008, UK regulators assessed on average two penalties per month, with an average value of $£ 555,499$ and a median value of $£ 100,000$. After Lehman Brothers went bankrupt, the count more than doubled to 4.46 penalties per month, with an average value of $£ 8.83$ million and a median value of $£ 187,829$ from 2009-2015.

Table 1 UK Regulatory Penalties

\begin{tabular}{|c|c|c|c|c|}
\hline & $\begin{array}{c}\text { Average } \\
(£ ’ 000 s)\end{array}$ & $\begin{array}{c}\text { Median } \\
(£ ' 000 s)\end{array}$ & Count & $\begin{array}{c}\text { Average Count } \\
\text { / Month }\end{array}$ \\
\hline $\begin{array}{c}\text { Before Lehman Brothers } \\
(1 / 1 / 02-15 / 9 / 08)\end{array}$ & $£ 555$ & $£ 100,000$ & 164 & 2 \\
\hline $\begin{array}{c}\text { After Lehman Brothers } \\
(15 / 9 / 08-30 / 9 / 15)\end{array}$ & $£ 8,830$ & $£ 187,829$ & 372 & 4.5 \\
\hline $\begin{array}{c}\text { Before Publication of Vickers } \\
\text { Report (1/1/02 - 12/9/11) }\end{array}$ & $£ 747$ & $£ 101,390$ & 342 & 3 \\
\hline $\begin{array}{c}\text { After Publication of Vickers } \\
\text { Report (12/9/11-30/9/15) }\end{array}$ & $£ 16,084$ & $£ 431,350$ & 194 & 4 \\
\hline
\end{tabular}

Source: Author's, using data from Financial Conduct Authority 
In aggregate, this increase is even more striking. From 2004-2006, the three-year average for the FSA’s total penalties was $£ 9.06$ million per \$1 trillion of GDP. During the 2013-2015 period, after much of the dust from the financial crisis had settled, this figure rises to $£ 358.1$ million—nearly a forty-fold increase.

We can also assess the transformation in the UK using comparative measures. Chart 1, which reports the adjusted penalty increases for the UK and the US, shows that prior to the financial crisis, the two countries were quite far apart in terms of regulatory enforcement, with several single regulatory fines by the SEC exceeding the combined monetary sanctions in the UK over an entire year; however, since the crisis, this gap has become much narrower, with total fines in the UK now exceeding those in the US in some years. Furthermore, when it comes to pursuing the same instance of misconduct, regulators in the UK and the US are now increasingly on the same page. For instance, the $£ 1.14$ billion the FCA assessed on five banks for illegal Forex trading in November 2014 was roughly similar in size to the $\$ 1.4$ billion ordered by the US Commodity Futures Trading Commission (CFTC) the same day (Financial Conduct Authority 2014; Commodity Futures Trading Commission 2014).

Chart 1 US and UK Penalties, 2004-015

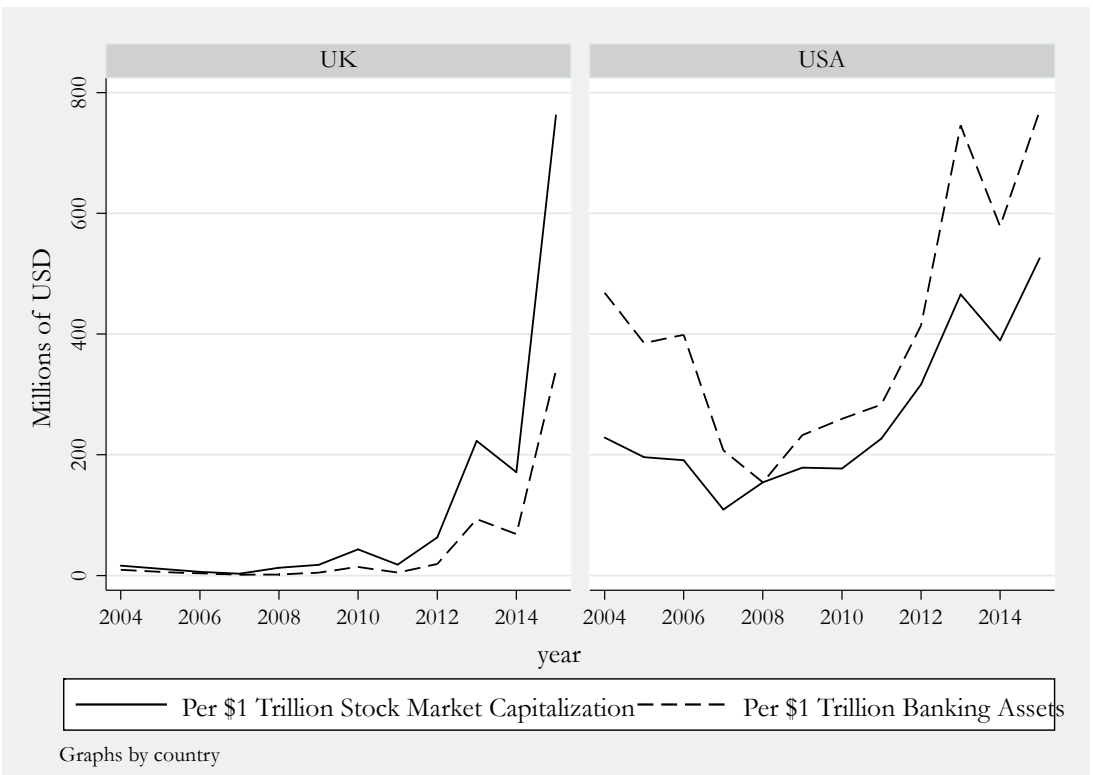

Source: Author's, using annual reports of Financial Conduct Authority (UK), Securities and Exchange Commission (US), Commodity Futures Trading Commission (US), Office of Comptroller of the Currency (US), and Federal Reserve (US), and economic data from Organization for Economic Cooperation and Development and International Monetary Fund

Finally, the pattern of enforcement intensity can be measured by examining insider trading convictions. As can be seen in Table 2, before the financial crisis, the FSA pursued only a handful of major enforcement actions for insider trading, and brought none of these cases to successful criminal prosecution. In 2009, the FSA secured its first insider trading convictions and, over the next year, convicted a total of six defendants for market abuse, imposing aggregate prison sentences of 83 months (ESMA 2012). In one investigation dubbed "Operation Tabernula," the 
UK regulator pursued simultaneous dawn raids on 16 different properties and searched the files of 140 staff of various financial institutions (The Telegraph 2015; see also Bloomberg News 2016). And in 2015, the FCA cases resulted in a record 14 people being sent to prison for insider tradingan approach that could hardly be described as light-touch (Financial Times 2015).

Table 2 UK Enforcement Statistics, Market Abuse

\begin{tabular}{|c|c|c|c|}
\hline Year & $\begin{array}{c}\text { Criminal Convictions for } \\
\text { Insider Trading }\end{array}$ & $\begin{array}{c}\text { Number of Prison } \\
\text { Sentences }\end{array}$ & $\begin{array}{c}\text { Avg. Length of } \\
\text { Prison Term } \\
\text { (months) }\end{array}$ \\
\hline 2004 & 0 & 0 & 0 \\
\hline 2005 & 0 & 0 & 0 \\
\hline 2006 & 0 & 0 & 0 \\
\hline 2007 & 0 & 0 & 0 \\
\hline 2008 & 0 & 0 & 0 \\
\hline 2009 & 4 & 4 & 13 \\
\hline 2010 & 4 & 2 & 25 \\
\hline 2011 & 3 & 3 & 22.7 \\
\hline 2012 & 11 & 11 & 36 \\
\hline 2013 & 2 & 2 & $\mathrm{n} / \mathrm{a}$ \\
\hline 2014 & 1 & 0 & unknown \\
\hline 2015 & 15 & 15 & \\
\hline
\end{tabular}

Source: Author's, using data from Financial Conduct Authority, ESMA and news reports

In sum, the enforcement approach in the UK has moved from "principles-based" regulation and light-touch enforcement toward more prescriptive modes of state supervision and more stringent approaches to enforcement. While this shift does indicate a modification of regulatory philosophy, it does not mean the financial services industry has become either less influential or less central to UK economic policy. Here, the American case is instructive: since the 1930's, American regulators have strictly enforced reporting and investor protection rules, and since the 1980s, punishment for insider trading has been quite punitive (Pitt and Shapiro 1990). Such enforcement approaches have hardly limited securities market development; indeed, the American system of adversarial legalism is seen by many scholars as facilitating the development of a robust securities market by either providing investors with actionable rights (La Porta et al. 2006) or ensuring that public actors protect investors and fair market conduct (Jackson and Roe 2009). Thus, to the extent that British regulatory enforcement focuses on measures such as investor protection or rooting out market misconduct, more intensive enforcement actions may be quite consonant with maintaining London as a financial centre. Examining 340 enforcement actions initiated by the FSA or FCA from 20092015, we can see that more than half of enforcement actions relate to market misconduct (109) or consumer protection (90), market-shaping measures long seen as enhancing securities market development. So far, at least, the UK appears to be following the US playbook, enforcing in areas that, in theory, should lead to a more robust securities market.

We can also examine trends in the size of UK financial services to assess whether increased enforcement has undermined the industry's predominance in the economy. Chart 2 reports the Gross Value Added (GVA) of finance and insurance services in the UK economy from 1997-2015. It is clear that financial and insurance services still remain highly central to the British economy. 
While declining slightly since their peak in 2009, financial and insurance services still constitute $7 \%$ of GDP - and this does not include the value of the real estate, legal, and consulting industries whose fortunes are largely tied to finance.

Chart 2 Gross Value Added of Financial and Insurance Services, UK, 1997-2015

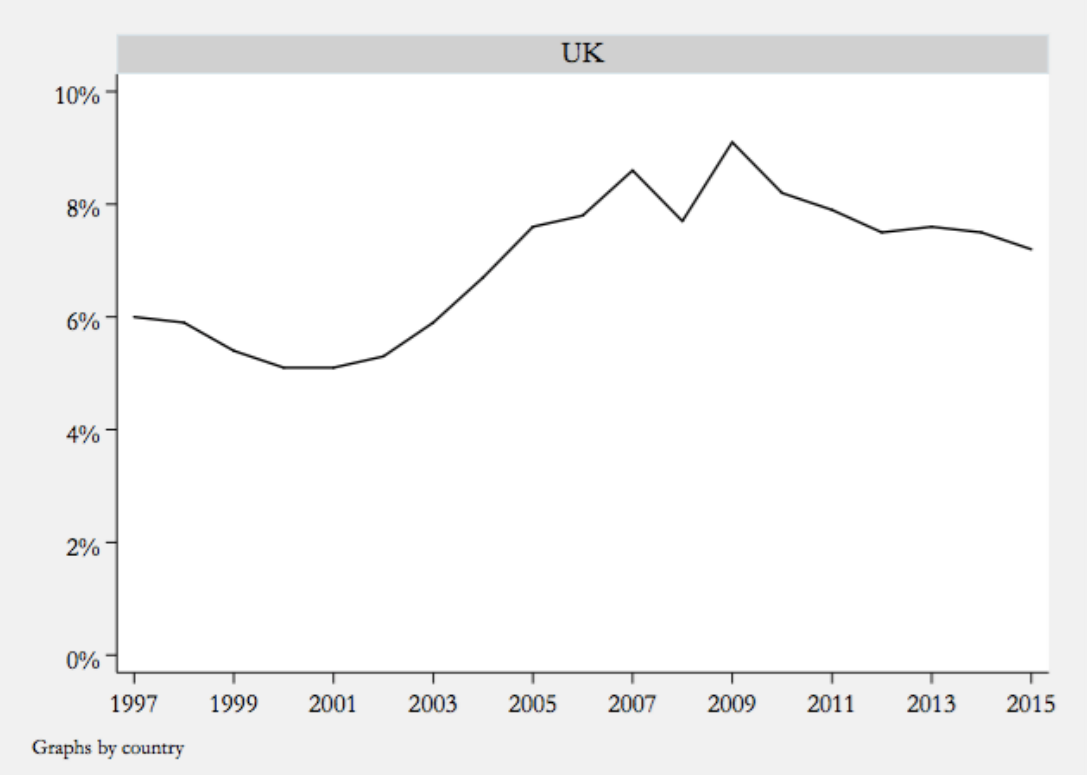

Source: Author's, using data from House of Commons

Finally, we can examine the actions of the British government over the last decade to assess the implications of the shift in supervision and enforcement. Politically, the promotion of the City's interests, while now more muted and containing more caveats, has nevertheless continued. At home, officials have avoided structural reforms that would reduce the concentration of banks, ban certain kinds of financial products, substantially raise taxes on banks or their employees, or promote a less financially-centred economic policy. Abroad, the UK has continued to actively promote the City's interests as well, lobbying for weak versions of European hedge fund regulations (Quaglia 2011), and successfully quashing a strong effort by the UK and France to promote a Financial Transaction Tax (Schulz 2017). Indeed, there are few signs that the crisis has resulted in more democratic or political controls of banks (Froud et al. 2010), or that there has been a sustained shift in the broader economic policy paradigm (Hodson and Mabbett 2009, 1056; Mügge 2013a).

Rather, what we observe is an adjustment of views among regulators about how best to maintain the UK's status as a global financial centre in the light of the crisis, and the new push for stricter regulatory practices at the European and international levels. While a light-touch regime was developed to promote London as a centre for international finance, it has now been retired to preserve that status. This shift in "regulatory instruments" does not reflect a deeper change in policy paradigm - UK policymakers remain as committed as ever to maintaining finance at the core of their economy (Hodson and Mabbett 2009; see also Hall 1993). 
However, the transformation from a laissez-faire model to a more adversarial and legalistic approach does evidence a change in beliefs about what regulatory instruments are best able to achieve these economic policy goals. Following the crisis, policymakers realized the limitations of the "light-touch" regulatory approach, and came to view the more adversarial and rule-based approach, long used in the U.S., as a better strategy for promoting the City of London's interests.

\section{France}

French financial regulation in the postwar period was guided by the combination of the Étatiste belief that state economic direction was needed to overcome the inherent irrationalities of the market, as well as nationalist views that finance should be structured in the French public interest. Consequently, until major financial privatization reforms were undertaken in France from 19841988, most major aspects of finance, both in the French banking system and in the much smaller Bourse, were guided directly or indirectly by the Treasury (Zysman 1983). The French securities regulator, the Commission des opérations de bourse (COB), was founded in 1967, but it remained a relatively obscure actor until government financial reforms in the mid-1980s substantially enlarged the French securities market and opened up participation to a wider variety of players (Story and Walter 1997, 215). Unlike in the UK where liberalization and re-regulation took the form of broad steering, but with generally hands-off approaches to the decisions of firms, in France, the state played an active role in the liberalization process (Levy 2005). This was no less true for finance, where French authorities privatized the major banks while spending vast sums to modernize the infrastructure of the Paris stock market. They also simultaneously pursued strong systems of supervision, borrowing ideas from the adversarial legalistic American regulatory system (Story and Walter 1997, 298). Within a few years, the COB was transformed from a body mostly involved in information gathering to one that possessed "sweeping powers to open inquiries, prevent trading by refusing mandatory authorizations, issue orders to cease trading, take cases to court, and levy fines" (Thatcher 2005, 363). During the early 2000s, France developed a "more coercive and judicialized" system (Kelemen 2011,119), establishing the Autorite des marchés financiers (AMF) with significant new powers to enforce securities rules related to market abuse. A similar shift toward confrontational regulation occurred in banking regulation. By 2006, monetary penalties were included in $85 \%$ of the French prudential regulators' decisions, compared to just $17 \%$ in 2001 (see Commission Bancaire 2007, 152).

In many respects, then, the turn toward liberal financial markets underpinned by strong supervision and stringent enforcement was part of France's pre-crisis economic strategy to foster a larger domestic financial market. Furthermore, by the time of the financial crisis, the French already had a market-shaping approach to regulation (Quaglia 2011) that was quite interventionist, adversarial, and sometimes punitive. All financial institutions were extensively monitored by state officials, who had usually graduated from either France's elite École polytechnique or École nationale d'administration, and any potential violations were heard before a quasi-judicial panel in a public proceeding. Moreover, unlike in the UK where criminal prosecutions were avoided until after the crisis, the French frequently pursued criminal cases throughout the 2000s.

Thus, when the financial crisis hit in 2008, with the most salient problems largely emerging from other markets, the French political class did not see their regulatory approach in securities markets as significantly implicated. Indeed, initially, the predominant view was that the broader French models of banking and regulation had been vindicated by the crisis, since the size of the French 
bailout was much smaller and handled more cooperatively than in other countries (Hardie and Howarth 2009; Woll 2014). If anything, the problem had been the regulatory laxity of foreign (and particularly American and British) jurisdictions. As French president Nicolas Sarkozy remarked in September 2008, ten days after the collapse of Lehman Brothers, "Self-regulation is finished. Laissez-faire is finished. The all-powerful market that is always right is finished" (Financial Times 2008). The fact that the French had never pursued a laissez-faire approach to liberalization, and indeed had championed a model of liberalization underpinned by strong state regulation, only reinforced French confidence in their domestic regulatory system following the crisis. Thus, in contrast to the UK, where the political and economic class came to believe that a new approach to regulation was needed to preserve the country's comparative advantage in finance, in France, there was little impetus to pursue a wholesale shift in the instruments of domestic supervision and enforcement. The national strategy of fostering more robust capital markets and developing strong European regulation could continue as before.

This continuity in French policy is also reflected in the domestic enforcement pattern. Chart 3 reports the aggregate penalties of the AMF. We can see that the incidence of monetary penalties remains relatively flat at the French securities regulator, with no discernible increase since the crisis. French authorities have continued to pursue high-profile securities cases, including a $€ 14$ million fine against an individual for insider trading in 2013 (Autorité des Marchés Financiers 2013) and two $€ 5$ million fines for high-frequency trading in 2015. However, there is little evidence that these prosecutions are different from the pre-crisis approach. For instance, in 2002, the COB fined George Soros $€ 2.2 \mathrm{M}$ for insider trading, which is generally in the same range as fines of today (New York Times 2002). And some of the highest-profile charges and convictions, such as the three-year criminal conviction against the rogue trader Jérôme Kerviel, were initiated well before the crisis and subsequent reforms (The Guardian 2010).

Chart 3 French Market Conduct Penalties, 2004-2014

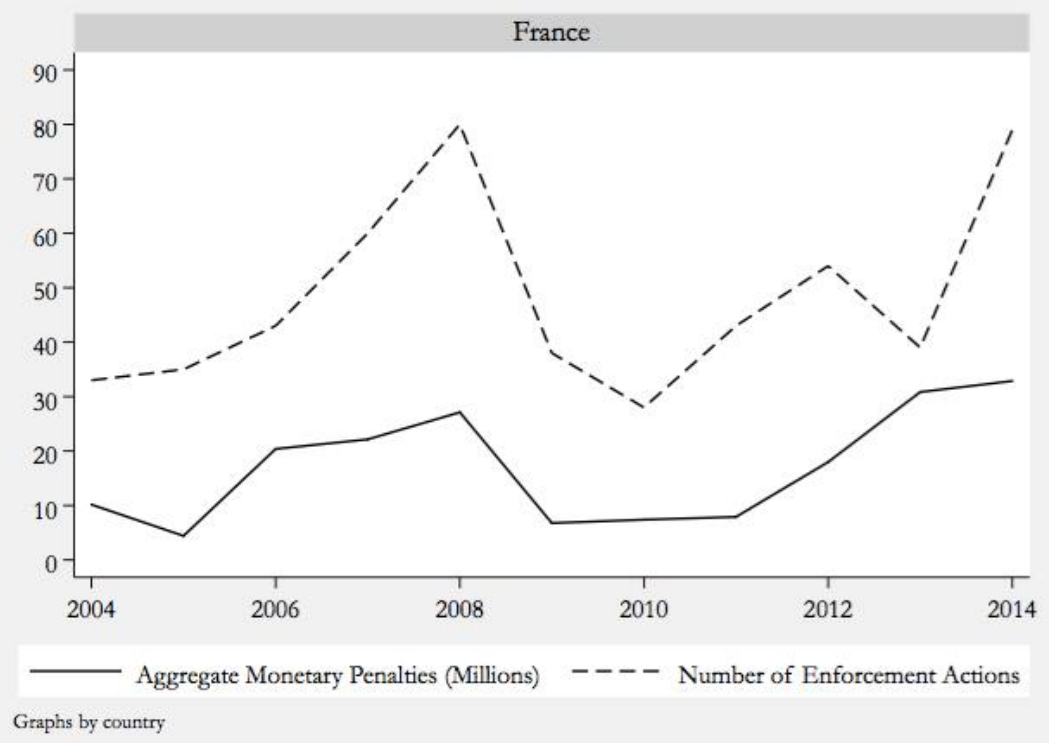

Source: Author's, using data from Autorité des Marchés Financie (AMF), Annual Reports 
Meanwhile, on the European level, the French government has been the leading advocate for addressing international "regulatory arbitrage" by developing more substantial supervisory harmonization on the European and international levels, particularly for areas like private equity, hedge funds, credit rating agencies, and other industries where British and American companies dominated international markets. In 2000, the French Treasury Minister, Laurent Fabius, proposed the establishment of a European securities regulator to be based in Paris, only to be rebuffed by the UK and Germany (Quaglia 2007: 282). In 2009, when France made a similar proposal, the political equation had changed because of the financial crisis. Two years later, the European Securities and Markets Association (ESMA) was established in Paris. Over the following years, the French government supported a variety of other market-shaping initiatives, such as a Financial Transaction Tax, stricter bank remuneration rules, and new hedge fund rules, while seeking to water down new capital requirements that would disproportionately affect some of its largest banks.

In sum, France's post-crisis regulatory approach largely followed its pre-crisis political strategy: domestically, it sought to maintain a strong system of state financial market supervision and enforcement; internationally, French policymakers continued to push for liberalized markets through state-led processes that provided the European Union with a strong rulemaking role. But in contrast to the UK, the comparatively positive experience of the crisis led French regulators to not see a shift in regulatory instrumentation as necessary to maintain domestic economic policy goals. What the crisis did alter was the French government's political capacity to achieve its goal of harmonized European financial supervision. By creating an impetus for European-level reform, the crisis helped French policymakers transform several longstanding proposals into reality.

\section{Germany}

In Germany, finance has traditionally been bank-dominated, and stock market development quite limited (Detzer and Herr 2014; Zysman 1983). Consequently, public securities enforcement was also quite weak: between 1975 and 1990, just one trader was caught for insider dealing in the entire country (Story and Walter 1997, 182). But just as in France, where the pressures of globalization and regulatory competition in the 1980 s resulted in the partial liberalization of a closed system, financial globalization and European integration undermined the traditional mode of West German financial regulation, especially after German reunification inspired additional financing needs. In response to calls by its biggest banks for a centralized and independent stock exchange, the federal government privatized the Frankfurt exchange, which housed $70 \%$ of German securities trading (Story and Walter 1997, 181). After 45 stock exchange members were caught in an insider-trading ring in 1991, Germany criminalized insider dealing, required public disclosure of most share listings, and established an independent securities regulator.

Over the next twenty years, the liberalization of German finance proceeded. Although important aspects of the three-pillar bank system were preserved (Vitols 2005), the reforms paved the way for the internationalization and marketization of Germany's private banks as well as some of its public savings banks (Hardie and Howarth 2009). It also led to the establishment in 2002 of the consolidated federal financial regulator, Bundesanstalt für Finanzdienstleistungsaufsicht (BaFin), which was given significant investigative and sanctioning powers. As an independent regulatory agency, BaFin had significant autonomy to apply the rules within a broad regulatory framework. However, the regulator took a less coercive and punitive approach than the AMF in France, giving weight to long-term relationships and showing forbearance to firms that cooperated. Although 
BaFin assessed hundreds of fines in the early 2000s, most were small fines assessed for reporting errors, and none were publicly reported.

German financial institutions were among the most exposed to the subprime mortgage crisis, and Germany had to spend a significant portion of its GDP bailing out the financial sector. But even if some of its largest banks were implicated in the crisis, its system of securities regulation was not. It had not been German under-regulation of the comparatively small Frankfurt Börse, after all, that had caused the subprime mortgage crisis or the Libor scandal. As in France, the German political class saw the crisis as stemming from inadequate enforcement abroad, not at home. As the German President of BaFin put it in May 2009: "We were very well aware that in some areas of the international financial system risk volumes had built up that were too high in comparison with the risk buffers that the banks held in the form of capital"; he then later implied that there was little that BaFin regulators could have done to regulate foreign markets (BaFin 2012). Consequently, the impetus to overhaul domestic German securities approaches was limited, even if Germany did enact several significant laws increasing regulatory stringency as part of broader efforts to strengthen European enforcement.

The pattern of continuity is reflected in the reported regulatory enforcement data. Table 3 , Column 1 reports the number of special audits, one of the primary regulatory tools used by the German federal regulator. Columns 2 and 3 indicate the number of insider trading investigations and convictions pursued by public prosecutors. While numbers can fluctuate from year to year, both indicators suggest a more or less stable, and slightly declining, enforcement volume following the crisis.

Table 3: Enforcement Sanctions, BaFin, 2004-2015

\begin{tabular}{|c|c|c|c|}
\hline BaFin Report & $\begin{array}{c}\text { Number of Special } \\
\text { Audits }\end{array}$ & $\begin{array}{c}\text { Insider Trading, New } \\
\text { Investigations }\end{array}$ & $\begin{array}{c}\text { Insider Trading, } \\
\text { Convictions }\end{array}$ \\
\hline 2004 & 324 & 57 & 5 \\
\hline 2005 & 335 & 54 & 9 \\
\hline 2006 & 287 & 51 & 11 \\
\hline 2007 & 280 & 42 & 3 \\
\hline 2008 & 244 & 44 & 6 \\
\hline 2009 & 258 & 30 & 11 \\
\hline 2010 & 258 & 34 & 2 \\
\hline 2011 & 270 & 31 & 5 \\
\hline 2012 & 273 & 51 & 8 \\
\hline 2013 & 305 & 27 & 1 \\
\hline 2014 & 203 & 46 & 1 \\
\hline 2015 & 176 & 41 & \\
\hline
\end{tabular}

Source: Author's, using data from BaFin Annual Reports

We can also see from BaFin reports that Germany has engaged in major legislative reforms that expand the breadth and depth of financial regulation, increasing liability for senior managers (Hänßler 2013) and enlarging the statutory maximum for sanctions multiple times over (Gibson Dunn 2013). However, the regulator has not yet applied more coercive sanctions in practice. In 2013, one of the few years where sanctioning data were published, 119 fines were imposed, totaling $€ 3.3$ million. The vast majority (97 of 119) of these were for violating information 
publication requirements (BaFin 2014, 85, Table 35, Administrative Fine Proceedings). While in the UK, fines are sometimes in the billions, and in France, the tens of millions, as of 2015, the highest fine ever imposed by BaFin against a company was $€ 3.5$ million against Blackrock for misrepresenting its ownership stakes in 50 German companies (Wall Street Journal 2015), while the highest fine against an individual remains $€ 215,000$ (von Buttlar 2016). Although the common defense for small fines is that most serious cases are referred to public prosecutors (Litsoukov 2015), in actuality, German prosecutions for securities violations rarely result in jail time-there are few cases, and among the cases that are pursued, prison sentences are almost always annulled. For instance, in 2009-2010, there were 67 criminal sanctions in Germany for insider trading, but only two involved prison sentences, both of which were annulled (ESMA 2012).

To the extent that we have seen a change in the tone of German enforcement, it appears to be defensive, prompted by the prospect of regulation from other national jurisdictions or the European Union. For instance, in the wake of intrusive investigations into the Deutsche Bank by US, UK, and European authorities, BaFin has criticized the bank for stressing profits over ethics, and sought to push the bank to remove its top leaders, singling out five of six for being complicit in the bank's involvement with LIBOR benchmark rate manipulation (New York Times 2015). However, such relatively weak interventions years after the LIBOR investigations by US, UK, and European authorities demonstrate that Germany is following, rather than leading, when it comes to the development of more confrontational enforcement approaches.

At the same time, there has been a steady, if gradual, shift in enforcement intensity over the last twenty years, as part and parcel of financial liberalization and the Europeanization of financial regulation. For instance, the percentage of cases involving fines moved from $12.4 \%$ of all proceedings commenced in 1996-1998 to 37\% for proceedings from 2013-2015 (von Buttlar 2016). And we see evidence that Germany is continuing to accept more public, adversarial, and stringent enforcement rules, adopting legislation in recent years that establishes whistleblower protections, substantially increases fines, and provides for the reporting of sanctions, despite strong concerns about the implications of such measures for German privacy protections. However, the use of new sanction powers by BaFin has so far been more tentative than in the French and UK cases, where, as we have seen, enforcement practices changed quite dramatically over a short period (in France before the crisis, and in the UK after). Consequently, we can expect that any changes that occur in German financial supervision in the years to come will likely remain incremental, as regulators use their discretion to ensure that domestic financial institutions have the time needed to understand, and adjust to, the more rule-based EU regulatory approach.

We can also see the continuation of Germany's pre-crisis economic strategy in its negotiations over new European rules. On the one hand, the government has been supportive of extending regulation in areas such as hedge funds, where there are no clear domestic interests (Quaglia 2011). But on the other hand, German negotiators have been openly hostile to attempts to establish European-level supervision over banking, out of concern that European Central Bank (ECB) supervision might undermine the ability of German cooperatives and public savings banks to maintain their distinct business models (Schulz 2017). And in some areas of European regulation, Germany has been the strongest opponent. For instance, the new European Banking Union was achieved largely over Germany's objections, and only after the government received an exemption from European supervision for all but a handful of Germany's banks (Howarth and Quaglia 2016). All in all, we can see that the German government has largely maintained its pre-crisis strategy of 
selectively supporting Europeanization in financial regulation, while gradually implementing European directives in ways that ensure that domestic financial structures can adjust to the new environment.

\section{Conclusion}

Industrial policy achieved through state ownership or direct subsidies has been in decline for several decades now. In the 21 st century, explicit industrial policy is deemed largely illegitimate, while many categories of industrial support are strictly forbidden under European competition law. Yet, the liberalization of finance, development of European law, and institutionalization of neoliberal ideas have not rendered states unable to promote national economic interests. As Clift and Woll (2013) note, liberalization has forced industrial policy to change, but it nevertheless has continued. "The integration of markets and the concurrent weaving together of regulatory frameworks," they explain, "put pressure on national economic intervention to eschew old-style industrial policy. Governments therefore had to become creative to assure traditional economic policy objectives with new means (309).”

In few policy areas has the prominence of "economic patriotism" been clearer than in finance, where European countries have transparently responded to liberalization by promoting domestic financial interests. Countries have selectively pursued liberalization where it was thought to advantage domestic financial groups, while supporting more 'embedded' markets in areas where domestic firms were less competitive. States have found creative ways to subsidize banks, whether through tax advantages or exemption from antitrust rules. Moreover, domestic regulatory systems have also been structured by these strategies, whether we examine the light-touch regulatory system adopted in the UK in the 1990s, the modernized, more coercive securities regulatory system developed in France in the early 2000's, or the cooperative and closed system of domestic regulation pursued in Germany.

Although the global financial crisis challenged these strategies, in all three countries, the central components of pre-crisis economic strategies were maintained, even if they had to be adjusted in light of the crisis. In the UK, the financial crisis delegitimized the light-touch approach to regulating securities and other financial markets, pushing British elites to overhaul their regulatory instruments and import more adversarial and rule-based enforcement approaches; however, this change was designed to maintain, not abandon, the promotion of UK financial interests in the European Single Market. In France, the crisis prompted few shifts in regulatory instruments at home, while opening up a window of opportunity to pursue long-standing goals to create more extensive European-level securities regulation that benefited Paris's status as a financial centre. Finally, in Germany, the crisis challenged key aspects of its three-pillar banking system, but prompted only gradual changes in regulatory instrumentation, and did not disrupt the government's pursuit of protections for favored domestic banks.

In sum, the financial crisis presented a mixture of challenges and opportunities for each country's national economic strategies, and while it led to some adjustments in policy, it did not force any country to abandon its overall strategy. At the same time, by pursuing this 21 st century "battle of the systems," governments in all three countries have also supported reforms that significantly expanded European authority over supervision and enforcement. Just as the European banking union may eventually "de-link banks from their sovereigns" (Gros 2013), centralized European 
securities enforcement may make it more difficult to pursue distinct national regulatory strategies in financial markets. With the new Market Abuse Regulation going into effect in 2016, ESMA continuing to develop its capacity and expand its orbit, and the ECB now actively supervising systemically important financial institutions (Moloney 2016), there will be significant new pressure to further institutionalize arms-length enforcement practices that rely more heavily on transparent sanctions and public punishment. Whether real financial supervisory harmonization is eventually achieved remains an open question. What is more certain is that European leaders will continue to face the legacy of heterogeneous financial systems and diverse industrial strategies for some time to come. 


\section{REFERENCES}

Marchés Financiers (AMF). 2013. "Use of inside information: AMF Enforcement Committee imposes its largest-ever fine." AMF News Release, November 14. http://www.amffrance.org/en_US/Actualites/Communiques-de-presse/Comission-dessanctions.html?docId=workspace\%3A\%2F\%2FSpacesStore\%2F597ed699-7605-43e0bca9-259a50d419cd

BaFin. 2012. "BaFin is ten years old: From lightning birth to maturity." BaFin Expert Articles, May https://www.bafin.de/SharedDocs/Veroeffentlichungen/EN/Fachartikel/2012/fa_bj_201205 bafin jubilaeum_en.html

\section{—. 2014. "BaFin 2013 Annual Report” BaFin Annual Report, June 17.}

Barth, James R., Gerard Caprio Jr., and Ross Levine. 2004. "Bank regulation and supervision: what works best?” Journal of Financial Intermediation 13 (2): 205-248.

- 2001. "The Regulation and Supervision of Banks Around the World: A New Database." Policy Research Working Paper No. 2588, World Bank.

Bloomberg News. 2016. "Five Stand Trial in Climax to Record U.K. Insider-Trading Case." Bloomberg News, January 8. https://www.bloomberg.com/news/articles/2016-01-08/fivestand-trial-in-climax-to-record-u-k-insider-trading-case?cmpid=yhoo.headline

von Buttlar, Julia. 2016. "Sanctions: First Act Amending Financial Markets Regulations - the new provisions of the German Securities Trading Act." BaFin Expert Articles, August 1 https://www.bafin.de/SharedDocs/Veroeffentlichungen/EN/Fachartike1/2016/fa bj_1607_s anktionen_en.html

Clift, Ben, and Cornelia Woll. 2013. "Economic patriotism: reinventing control over open markets." Journal of European Public Policy 19 (3): 307-323.

Coen, David, and Mark Thatcher. 2008. "Network Governance and Multi-Llevel Delegation: European Networks of Regulatory Agencies.” Journal of Public Policy 28 (1): 49-71.

Coffee, John C. 2007. "Law and the Market: The Impact of Enforcement." University of Pennsylvania Law Review 156 (2): 229-311.

Commission Bancaire. 2007. "2006 Annual Report.” Commission Bancaire France.

Commodity Futures Trading Commission. 2014. "CFTC Orders Five Banks to Pay over \$1.4 Billion in Penalties for Attempted Manipulation of Foreign Exchange Benchmark Rates." $\begin{array}{lllll}\text { Commodity Futures Trading Commission } & \text { (CFTC), Nov } 12\end{array}$ http://www.cftc.gov/PressRoom/PressReleases/pr7056-14.

Deeg, Richard. 1999. Finance Capitalism Unveiled: Banks and the German Political Economy. University of Michigan Press. 
Detzer, Daniel, and Hansjörg Herr. 2014. "Financial Regulation in Germany." Working Paper No. 55. FESSUD: Financialisation, Economy, Society, and Sustainable Development.

European Security and Markets Association (ESMA). 2012. "Report: Actual use of sanctioning powers under MAD.” ESMA/2012/270, April 26.

Ferran, Eilis. 2006. 'The liberalisation of financial markets: the regulatory response in the United Kingdom.' In The Regulation of International Financial Markets - Perspectives for Reform, edited by Rainer Grote and Thilo Marauhn, 59-62. Cambridge, Cambridge University Press.

Financial Conduct Authority (FCA). 2014. "FCA fines five banks $£ 1.1$ billion for FX failings and announces industry-wide remediation programmes.” $\quad$ Nov 12. http://www.fca.org.uk/news/fca-fines-five-banks-for-fx-failings

Financial Services Authority. 2009. "The Turner Review - A regulatory response to the global banking crisis.”, London, Financial Services Authority. http://www.fsa.gov.uk/pubs/other/turner review.pdf

Financial Times 2015. "UK City regulator raises jail term tally to 14 from 2." December 27. https://www.ft.com/content/d6bd7b08-aa4c-11e5-955c-1e1d6de94879?mhq5j=e2

- 2008. "Sarkozy says era of laissez-faire is finished." Financial Times, September 26 http://www.ft.com/cms/s/0/232b839a-8b65-11dd-b634$0000779 \mathrm{fd} 18 \mathrm{c} . \mathrm{htm} l \mathrm{ft}$ site $=$ falcon\&desktop=true $\#$ axzz41DkSBW2U

Froud, Julie, Michael Moran, Ariana Nilsson, and Karel Williams. 2010. "Wasting a crisis? Democracy and markets in Britain after 2007." The Political Quarterly 81 (1): 25-38.

Gibson Dunn. 2013. "Tenfold Increase Of Corporate Fines For Compliance Violations In Germany." July 9. Accessible at $<$ http://tinyurl.com/y9so3jee $>$. Last accessed Oct. 1, 2017.

Goldstein, Morris, and Nicolas Véron. 2011. “Too Big to Fail: The Transatlantic Debate.” Peterson Institute for International Economics.

Goodhart, Charles AE. 2001. "Regulating the Regulator: An Economist's Perspective on Accountability and Control." In Regulating Financial Services and Markets in the TwentyFirst Century, edited by Eilis Ferran and Charles AE Goodhart. Oxford: Richard Hart.

Gros, Daniel. 2013. "Banking Union with a Sovereign Virus: The self-serving regulatory treatment of sovereign debt in the euro area." CEPS Policy Brief, March 2013. https://www.ceps.eu/system/files/PB\%20No\%20289\%20DG\%20BU\%20with\%20a\%20So vereign $\% 20$ Virus.pdf

Grossman, Emiliano. 2006. "Europeanization as an Interactive Process: German Public Banks Meet EU State Aid Policy.” Journal of Common Market Studies 44 (2): 325-342.

Grossman, Emiliano, and Patrick Leblond. 2011. "European Financial Integration: Finally the Great Leap Forward?” Journal of Common Market Studies 49 (2): 413-435. 
Grossman, Emiliano, and Cornelia Woll. 2014. "Saving the Banks: The Political Economy of Bailouts.” Comparative Political Studies 47 (4): 574-600.

The Guardian. 2010. "French rogue trader Jérôme Kerviel sentenced to jail and €4.9bn fine." October 5. https://www.theguardian.com/business/2010/oct/05/jerome-kerviel-jail-sentence

Hall, Peter. 1993. "Policy Paradigms, Social Learning, and the State: The Case of Economic Policymaking in Britain.” Comparative Politics 25 (3): 275-296.

Handke, Stefan, and Hubert Zimmermann. 2012. "Institutional Change in German Financial Regulation." In Crisis and Control: Institutional Change in Financial Market Regulation, edited by Mayntz, Renate. Max Planck Institute for the Study of Societies, Cologne, Germany.

Hardie, Iain, and David Howarth. 2009. "Die Krise but not La Crise? The Financial Crisis and the Transformation of German and French Banking Systems." Journal of Common Market Studies 47 (5): 1017-1039.

Hardie, Iain, David Howarth, Sylvia Maxfield, and Amy Verdun. 2011. "Zysman Thirty Years On: The Political Economy of Finance Revisited." Unpublished manuscript. Victoria: University of Victoria.

Hänßler, Nadine. 2013. "Senior management: Criminal sanctions for deficiencies in business organisation." BaFin Expert Articles, September 16. http://www.bafin.de/SharedDocs/ Veroeffentlichungen/EN/Fachartikel/2013/fa bj 201309 sanktionierung gl en.html

Höpner, Martin, and Lothar Krempel. 2004. "The Politics of the German Company Network." Competition \& Change 8 (4): 339-356.

Horáková, Martina, and Amy Jordan. 2014. The Directory of Financial Regulators. London: Risk Books.

Hodson, Dermot, and Deborah Mabbett. 2009. "UK Economic Policy and the Global Financial Crisis: Paradigm Lost?” Journal of Common Market Studies 47 (5):1041-1061.

Howarth, David, and Lucia Quaglia. 2016. The Political Economy of Banking Union. London: Oxford University Press.

_ 2013. "Banking on Stability: The Political Economy of New Capital Requirements in the European Union," Journal of European Integration 35 (3): 333-346.

Jackson, Howell E. 2007. "Variation in the Intensity of Financial Regulation: Preliminary Evidence and Potential Implications." Harvard Law School John M. Olin Center for Law, Economics and Business Discussion Paper Series. Paper 521.

Jackson, Howell E., and Mark J. Roe. 2009. "Public and private enforcement of securities laws: Resource-based evidence.” Journal of Financial Economics 93 (2): 207-238. 
James, Scott. 2016. "The domestic politics of financial regulation: Informal ratification games and the EU capital requirement negotiations," New Political Economy 21(2): 187-203.

Johal, Sukhdev, Michael Moran, and Karel Williams. 2012. "The future has been postponed: The Great Financial Crisis and British politics.” British Politics 7 (1): 69-81.

Kagan, Robert. 2003. Adversarial Legalism. Cambridge, MA: Harvard University Press.

Kelemen, Dan. 2011. Eurolegalism: The Transformation of Law and Regulation in Europe. Cambridge, MA: Harvard University Press.

Kelemen, R. Daniel, 2006, "Suing for Europe: Adversarial Legalism and European Governance." Comparative Political Studies 39 (1): 101-127.

Lannoo, Karel. 2013. "The New Financial Regulatory Paradigm: A transatlantic perspective." CEPS Policy Brief, No. 287, March.

La Porta, Rafael, Florencio Lopez-de-Silanes, and Andrei Shleifer. 2006. "What works in securities law?" The Journal of Finance 61(1): 1-32.

Levy, Jonah. 2005. "Redeploying the State: Liberalization and Social Policy in France.” In Beyond Continuity: Institutional Change in Advanced Political Economies, edited by Wolfgang Streeck and Kathleen Thelen, 103-126. Oxford University Press.

Litsoukov, Nikita. 2015. "BaFin and the SEC: An international comparison of supervisory practice," BaFin Expert Articles. https://www.bafin.de/SharedDocs/Veroeffentlichungen/EN/ Fachartikel/2015/fa bj_1510_bafin_und_sec_en.html

Moloney, Niamh. 2011. "Reform or Revolution? The Financial Crisis, EU Financial Markets Law, and the European Securities and Market Authority." International and Comparative Law Quarterly 60 (2): 521-533.

- 2016. "Institutional Governance and Capital Markets Union: Incrementalism or a 'Big Bang'?" European Company and Financial Law Review 13 (2): 376-423.

Moran, Michael. 1986. Politics of Banking: The Strange Case of Competition and Credit Control. Macmillan Press.

Morgan, Glenn. 2012. "Supporting the City: economic patriotism in financial markets." Journal of European Public Policy 19 (3): 373-387.

Morin, François. 2000. “A transformation in the French model of shareholding and

Management." Economy and Society 29 (1): 36-53.

Mügge, Daniel. 2013a. "Resilient neo-liberalism in European financial regulation." In Resilient Liberalism in Europe's Political Economy, edited by Vivien Schmidt and Mark Thatcher, 201-225. Chicago: Cambridge, University Press. 
- 2013b. "The Political Economy of Europeanized Financial Regulation." Journal of European Public Policy 30 (2): 458-470.

- 2011. Widen the Market, Narrow the Competition: Banker Interests and the Making of a European Capital Market. ECPR Press.

New York Times. 2015. "Deutsche Bank Shake-Up Should Improve Accountability." October 20. https://www.nytimes.com/2015/10/20/business/dealbook/deutsche-bank-shake-up-shouldimprove-accountability.html

- 2002. "Soros is Found Guilty in France on Charges of Insider Trading." New York Times, December 21. http://www.nytimes.com/2002/12/21/business/soros-is-found-guilty-infrance-on-charges-of-insider-trading.html

Pitt, Harvey L. and Karen L. Shapiro. 1990. "Securities Regulation By Enforcement: A Look Ahead At the Next Decade," Yale Journal on Regulation 7(1): 149-304.

Posner, Elliot and Nicolas Véron. 2012. "The EU and financial regulation: power without purpose? Journal of European Public Policy 17(3): 400-415.

Quaglia, Lucia. 2012. “The 'Old' and 'New' Politics of Financial Services Regulation in the EU." New Political Economy 17:4, 515-535.

- 2011. "The 'Old' and 'New' Political Economy of Hedge Fund Regulation in the European Union.” West European Politics 34 (4): 665-682.

- 2007. "The politics of financial services regulation and supervision reform in the European Union.” European Journal of Political Research 46 (2): 269-290.

Schulz, Daniel. 2017. "Varieties of Crisis Responses in the EU: Does capitalist diversity prevent radical reforms of financial regulation?" Working Paper. Accessed on June 28, 2017 http://eui.academia.edu/DanielFSchulz

Shonfield, Andrew. 1965. Modern capitalism: the changing balance of public and private power. Oxford University Press.

Story, Jonathan, and Ingo Walter. 1997. Political economy of financial integration in Europe: The battle of the systems. Cambridge, MA: MIT Press.

Talani, Leila Simona. 2011. "The impact of the global financial crisis on the City of London: towards the end of hegemony?" Competition and Change 15 (1): 11-30.

The Telegraph. 2015. "Operation Tabernula: The story of the biggest insider trading investigation in UK history." March 19. http://www.telegraph.co.uk/finance/financialcrime/11483111/Operation-Tabernula-The-story-of-the-biggest-insider-tradinginvestigation-in-UK-history.html 
Thatcher, Mark. 2005. "The Third Force? Independent Regulatory Agencies and Elected Politicians in Europe," Governance: An International Journal of Policy, Administration, and Institutions 18(3): 347-373.

Tomasic, Roman. 2010. "Beyond 'light-touch' regulation of British banks after the financial crisis." In The Future of Financial Regulation, edited by Iain MacNeil and Justin O'Brien, 103-122. Oxford: Hart Publishing.

Vitols, Sigurt. 2005. “Changes in Germany's Bank-Based Financial System: Implications for Corporate Governance.” In Corporate Governance: An International Review 13 (3): 386-396.

Vogel, Steven K. 1996. Freer Markets, More Rules: Regulatory Reform in Advanced Industrial Countries. Cornell University Press.

Wall Street Journal. 2015. "BlackRock Hit with Record Fine by German Regulator BaFin.” March 2. http://www.wsj.com/articles/blackrock-hit-with-record-fine-by-german-regulator-bafin1426852194

Woll, Cornelia. 2014. The Power of Inaction: Bank Bailouts in Comparison. Ithaca, NY: Cornell University Press.

Zysman, John. 1983. Governments, Markets, and Growth: Financial Systems and the Politics of Industrial Change. Ithaca, NY: Cornell University Press. 
Published by the Centre for European Studies at Carleton University, Ottawa, Canada Available online at: journals.carleton.ca/rera/index.php/rera

RERA is an electronic academic peer-reviewed journal that publishes graduate, post-graduate, and young scholarly works. Topics relate to the European Union, its Member States, the former Soviet Union, and Central and Eastern Europe. The journal is a joint project supported by the CanadaEurope Transatlantic Dialogue - a cross-Canada research network supported by the Social Sciences and Humanities Research Council of Canada (SSHRC) — along with the Institute of European, Russian and Eurasian Studies (Carleton University) and its associated research unit, the Centre for European Studies.

RERA aims to provide an accessible forum for research, to promote high standards of research and scholarship, and to foster communication among young scholars.

\section{Contact:}

Carleton University

The Centre for European Studies

1103 Dunton Tower

1125 Colonel By Drive

Ottawa, ON K1S 5B6

Canada

Tel: +01 613 520-2600 ext. 3117; E-mail: rera-journal@ carleton.ca

\section{Creative Commons License}

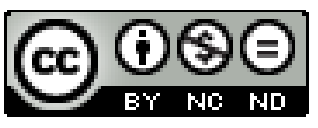

creativecommons.org/licenses/by-nc-nd/3.0

This Working Paper is licensed under a Creative Commons Attribution-Non-CommercialNo Derivs 3.0 Unported License (CC BY-NC-ND 3.0).

Articles appearing in this publication may be freely quoted and reproduced, provided the source is acknowledged. No use of this publication may be made for resale or other commercial purposes.

ISSN: 1718-4835

(C) 2018 The Author(s) 